\title{
Report Version Physician Sign Off Indicator
}

National Cancer Institute

\section{Source}

National Cancer Institute. Report Version Physician Sign Off Indicator. NCI Thesaurus.

Code C94059.

Specifies whether the physician has reviewed and signed off on a version of a report. 